\title{
Article
}

\section{The Mobile Phone in the Diffusion of Knowledge for Institutional Quality in Sub-Saharan Africa}

Asongu, Simplice A. and Nwachukwu, Jacinta Chikaodi

Available at http://clok.uclan.ac.uk/24919/

Asongu, Simplice A. and Nwachukwu, Jacinta Chikaodi ORCID: 0000-00032987-9242 (2016) The Mobile Phone in the Diffusion of Knowledge for Institutional Quality in Sub-Saharan Africa. World Development, 86 . pp. 133147. ISSN 0305-750X

It is advisable to refer to the publisher's version if you intend to cite from the work.

http://dx.doi.org/10.1016/j.worlddev.2016.05.012

For more information about UCLan's research in this area go to http://www.uclan.ac.uk/researchgroups/ and search for <name of research Group>.

For information about Research generally at UCLan please go to http://www.uclan.ac.uk/research/

All outputs in CLoK are protected by Intellectual Property Rights law, including Copyright law. Copyright, IPR and Moral Rights for the works on this site are retained by the individual authors and/or other copyright owners. Terms and conditions for use of this material are defined in the policies page.

\section{CLoK}

Central Lancashire online Knowledge www.clok.uclan.ac.uk

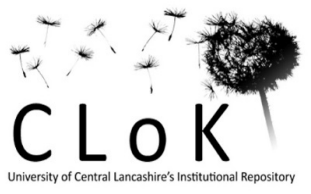




\section{$\underline{\text { A G D I Working Paper }}$}

\section{$\mathrm{WP} / 16 / 010$}

The Mobile Phone in the Diffusion of Knowledge for Institutional Quality in SubSaharan Africa

Forthcoming: World Development

Simplice Asongu

African Governance and Development Institute,

P. O. Box 8413, Yaoundé, Cameroon.

E-mail: asongusimplice@yahoo.com

\section{Jacinta C. Nwachukwu}

Department of Economics, Finance and Accounting,

Faculty of Business, Environment and Society,

Coventry University

Priory Street, Coventry, CV1 5DH, UK

Email: jacinta.nwachukwu@coventry.ac.uk 


\title{
AGDI Working Paper
}

Research Department

The Mobile Phone in the Diffusion of Knowledge for Institutional Quality in Sub-Saharan Africa

\author{
Simplice A. Asongu \& Jacinta C. Nwachukwu
}

March 2016

\begin{abstract}
This study assesses the mobile phone in the diffusion of knowledge for better governance in sub-Saharan Africa for the period 2000-2012. For this purpose we employ Generalised Method of Moments with forward orthogonal deviations. The empirical evidence is based on three complementary knowledge diffusion variables (innovation, internet penetration and educational quality) and ten governance indicators that are bundled and unbundled. The following are the main findings. First, there is an unconditional positive effect of mobile phone penetration on good governance. Second, the net effects on political, economic and institutional governances that are associated with the interaction of the mobile phone with knowledge diffusion variables are positive for the most part. Third, countries with low levels of governance are catching-up their counterparts with higher levels of governance. The above findings are broadly consistent with theoretical underpinnings on the relevance of mobile phones in mitigating bad governance in Africa. The evidence of some insignificant net effects and decreasing marginal impacts may be an indication that the mobile phone could also be employed to decrease government quality. Overall, this study has established net positive effects for the most part. Five rationales could elicit the positive net effects on good governance from the interaction between mobile phones and knowledge diffusion, among others, the knowledge variables enhance: reach, access, adoption, cost-effectiveness and interaction. In a nut shell, the positive net effects are apparent because the knowledge diffusion variables complement mobile phones in reducing information asymmetry and monopoly that create conducive conditions for bad governance. The contribution of the
\end{abstract}


findings to existing theories and justifications of the underlying positive net effects are discussed.

JEL Classification: G20; O38; O40; O55; P37

Keywords: Mobile phones; Governance; Africa

\section{Introduction}

Positioning an inquiry on the relevance of knowledge diffusion in mobile phone penetration $^{1}$ for institutional quality in sub-Saharan Africa (SSA) is motivated by at least six important currents in recent literature.

First, the phenomenon of globalisation is now an ineluctable process whose challenges can be neglected only by sacrificing the prosperity of nation states. Accordingly, there is a growing consensus in the literature that in the current era of globalisation, for nations to be competitive and well-integrated into the global economy, they need competitive edges in a number of fields (Tchamyou, 2015; Oluwatobi et al., 2015; Asongu, 2015a). According to the narrative, competition in the $21^{\text {st }}$ century is fundamentally centred on the ability of a nation to acquire and diffuse new knowledge. The concept of knowledge economy (KE) has been mastered by Europe and North America which are inexorably setting the course of development in the international arena. Moreover, the historic pattern formulated by Japan has influenced the KE courses of Malaysia, China and the Newly Industrialized Economies of Asia (Hong Kong, Singapore, South Korea and Taiwan). Whereas other Asian and Latin American nations have been responding in calculated strategies that articulate the quest for $\mathrm{KE}$ in their growing pursuits of national and regional initiatives, the overall knowledge index of Africa has been dropping (see, Anyanwu, 2012; Asongu, 2015b). It follows that there is a policy syndrome of $\mathrm{KE}$ in African countries when compared with their developed and developing counterparts.

Second, in terms of mobile phones, frontier markets of Europe, Asia and North America have been witnessing some stabilization in growth (Asongu, 2015a). This trend is in accordance with Penard et al. (2012) who concluded that, as of 2010, penetrations rates of the internet and mobile phones in Africa were not symmetrical. According to the authors, while mobile and internet penetration rates have attained saturation points in developed countries, African nations are currently experiencing some asymmetric development in the engaged

\footnotetext{
${ }^{1}$ For the purpose of simplicity, the terms 'mobile phone', 'mobile', 'mobile telephony' and 'mobile phone penetration' are used interchangeably throughout the study.
} 
information and communication technologies (ICTs), notably with 41\% (9.6\%) for mobile (internet) penetration. In light of this fact, it is apparent that the mobile phone still has important potentials in Africa, which could represent important development opportunities if well-tailored towards critical development outcomes.

Third, there are growing requests in scholarly and policy-making circles for the mobile phone not to be considered as a silver bullet of development (see Mpogole et al., 2008, p. 71; Asongu \& De Moor, 2015a). Within this skeptical framework, authors have recommended more scholarly research on the development outcomes of mobile phones.

Fourth, a World Bank report of April 2015 on Millennium Development Goals (MDGs) shows that poverty has been decreasing in all regions of the world, with the exception of SSA, where about $45 \%$ of countries in the sub-region as still far-off from reaching the MDGs extreme poverty target (see World Bank, 2015). This dismal evidence substantially contrast with the sub-region enjoying more than two decades of growth resurgence that began in the mid 1990s (see Fosu, 2015a, p. 44). The immiserizing growth in the sub-region has also motivated a recent stream of institutional literature, notably, some recent books by: (i) Fosu (2015bc) on the nexus between growth and institutions in African development which aims to elicit whether the recent growth resurgence experienced by the sub-region is a myth or a reality and (ii) Kuada (2015) on the need to lay more emphasis on soft economics or human capability development for understanding development trends in the sub-region.

Fifth, government quality has been documented in recent literature to be strongly associated with inclusive growth, notably, in: improving standards of living through more efficient allocation of economic resources (Fosu, 2013ab; Anyanwu \& Erhijakpor, 2014; Fonchingong, 2014) and consolidating the basis of social change (Efobi, 2015).

Sixth, the growing literature on development outcomes from mobile phone penetration has scarcely engaged the effect on government quality in the sub-region, in spite of the documented role of mobile phones (Asongu, 2015c) and quality of institutions (Fosu, 2015bc) in inclusive development. In essence, to the best of our knowledge there are currently only four studies that have been positioned on the role of mobile phones in institutional quality in Africa (Snow, 2009; Mathias, 2012; Gagliardone, 2015; Porter et al., 2015). (1) Snow (2009) has established a negative nexus between a nation's mobile phone penetration rate and her perceived corruption level. The growing role of connectivity in consolidating accountability in Africa has been documented by Mathias (2012). The nexus between government quality 
and mobile-radio interactions has been assessed by Gargliardone (2015) who has concluded that the underlying interactions can significantly enhance government's efforts towards more corrective and preventive measures in Kenya. Porter al. (2015) position an inquiry on South Africa, Malawi and Ghana to establish that the burgeoning mobile usage by the youth on the continent has potentials to be tailored towards greater harmony between practice and policy.

Noticeably, the discussed literature leaves room for improvement in at least five areas. First, contrary to engaged country-specific studies that are characterised with policy implications of limited scope, it is important to position inquiries on broader sets of countries for results with policy outcomes of greater application scope (see Porter al., 2015; Snow, 2009). Second, the engaged literature has focused on limited dimensions of government quality. This is the case with Snow (2009) who focuses on corruption which is only an aspect of institutional governance. Third, some inquiries have either not directly linked institutional quality to policy outcomes (see Porter et al., 2015) or not directly focused on the employment of mobile phones for greater government quality (see Gagliardone, 2015). Fourth, some findings have cautious policy implications because the underlying empirical analyses are statistically fragile. For example, whereas Snow (2009) has concluded on a negative nexus between mobile phones and corruption, the findings should be welcomed with caution because they are not based on causality but on correlations. Fifth, on the complementarity between KE and mobile phones, Gargliardone (2015) has used mobile-radio interactions. We employ three KE variables.

The present study addresses above first-four gaps by assessing the role of the mobile phone in the diffusion of knowledge for government quality in SSA. The empirical evidence is based on a panel of 49 African countries and an endogeneity-robust Generalised Method of Moments (GMM) with forward orthogonal deviations. The knowledge diffusion variables on which the mobile phone is interacted in order to address the fifth gap are: education, innovation and internet penetration. Ten governance indicators are used consisting of six unbundled variables (voice \& accountability, political stability/no violence, corruptioncontrol, rule of law, government effectiveness and regulation quality) and four bundled indicators (political, economic, institutional and general governance dynamics). The purpose of bundling and unbundling governance indicators is to avail room for robustness and more policy implications.

The rest of the study is structured as follows. In Section 2, we clarify the concepts of governance and mobile (m) governance on the one hand and present the intuition and 
theoretical underpinnings on the other hand. The data and methodology are covered in Section 3. Section 4 presents and discusses the empirical results while Section 5 concludes with implications and future directions.

\section{Clarification of governance concepts and theoretical highlights}

\subsection{Intuition and Theory}

Consistent with Hellstorm (2008), ICTs are important instruments for improving governance because they enhance accountability, openness, transparency and free-flow of information between various departments and institutions within a government. The narrative sustains that the mobile phone also facilitates information diffusion between the government and citizens on the one hand and the direct participation of citizens in the making of decisions that affect their livelihoods on the other hand. In summary, the above are also achieved by the overall appeal of the mobile phone in converging societies for better connection, participation, innovation and information.

With the above intuition in mind, Snow (2009, pp. 337-339) has documented the theoretical underpinnings linking the mobile phone to better government quality. According to the theory, the historic dearth of ICTs in Africa endowed the elite with preferential ICTs facilities. This edge in ICTs substantially constrained transparency and accountability in the management of government offices. Hence, the elite were confronted with good conditions for corruption and mismanagement of public goods. Conversely, with the rapid and massive diffusion of ICTs in general and the mobile telephony in particular, opportunities for rentseeking and capitalising on information asymmetry for corrupt purposes are being increasingly reduced. In essence, the author postulates that decentralisation of ICT has broken secrecy barriers that until now have prevented, inter alia: the detection of corruption in public/private circles as well as oversight and punishment of corrupt officials. In a nutshell, the logic underpinning this theory essentially builds on the intuition discussed by Hellstorm (2008), notably: the mobile has substantially reduced the longstanding monopoly of information by the elite which resulted in corrupt behaviour and mismanagement.

\subsection{Clarification of governance and mobile (m)-governance concepts}

This section is engaged in four principal strands, namely: the concept of (m)governance, some definitions of governance documented in recent literature, debates on the 
quality of mainstream governance indicators and the policy relevance of bundling and unbundling institutions.

The first strand clarifies the concept of m-governance. In accordance with Hellstorm (2008), m-governance should be understood as the use of ICT to improve benefits by parties engaged in electronic (e)-governance. These parties include, inter alia: government units, citizens and business units. Hellstorm sustains that the usage of mobile telephony to enhance government quality consists of using the mobile phone to improve, among others: citizenary participation, public service delivery and respect of institutions within a nation.

In the second strand, there are a plethora of definitions to the governance concept. For the interest of brevity, we are consistent with Asongu (2015d) in discussing four main definitions in light of recent literature. (1) Dixit (2009) defines economic governance as the “ '...structure and functioning of the legal and social institutions that support economic activity and economic transactions by protecting property rights, enforcing contracts, and taking collective action to provide physical and organizational infrastructure ${ }^{2}$ (p.5). (2) According to Fukuyama (2013), the concept of governance can be consolidated by the comprehension of four principal approaches to 'state quality', namely: capacity indicators which encompass professionalism and resource levels, political measures and output indicators. (3) In accordance with Tusalem (2015), governance is a phenomenon that embodies: the rule of law, regulation quality, bureaucratic effectiveness and corruption. (4) To the best of our knowledge, the most popular governance indicators are those from Kaufmann et al. (2010). The corresponding six indicators are classified into three categories, namely: (i) 'institutional governance' which is the respect of the State and citizens of institutions that govern interactions between them (measured with corruption-control and the rule of law); (ii) 'political governance' which is the election and replacement of political leaders (proxied with political stability/no violence and voice and accountability) and (iii) 'economic governance', which is defined as the formulation and implementation of policies that deliver public commodities (measured with government effectiveness and regulation quality).

The third strand is concerned with criticisms associated with application of the underlying Kaufmann et al. (2010) indicators. Accordingly, despite some criticisms in scholarly circles, Kaufmann, Kraay and Mastruzzi have been promptly responding to critics. One of the most interesting debates (to the best of our knowledge) has been with Andrew Schrank and Marcus Kurtz. For brevity and lack of space, we invite the interested reader to

\footnotetext{
${ }^{2}$ Emphasis on original.
} 
consult the main currents underlying the debate, namely: measures and mechanisms (Kurtz \& Schrank, 2007a); a reply (Kaufmann et al., 2007a) ; a defense (Kurtz \& Schrank, 2007b) and a rejoinder (Kaufmann et al., 2007b).

In the last strand, we devote space to articulating the intuition for bundling and unbundling governance indicators in order to present findings with more robustness and greater room for policy implications. For this purpose, the six governance indicators from Kaufmann et al. are bundled into political, economic, institutional and general governances. The relevance of unbundling and bundling governance variables is in accordance with an evolving stream of literature on institutional quality in Africa, notably: (i) predicting the Arab Spring based on negative governance signals (Asongu \& Nwachukwu, 2015a); (ii) economic governance as the most important determinant of innovation (Oluwatobi et al., 2015) and (iii) governance tools in the fight against software piracy (Andrés \& Asongu, 2013) and conflicts/crimes (Asongu \& Kodila-Tedika, 2016) in Africa. Beyond the framework of African institutonal literature, the six governnce indicators from Kaufmann et al. (2010) have been considered in other branches of governance literature (see Gani, 2011; Andrés et al., 2014; Yerrabit \& Hawkes, 2015).

\section{Data and methodology}

\subsection{Data}

This study examines a panel of forty-nine nations in SSA with data from World Bank Development Indicators for the period 2000-2012. In accordance with Tchamyou (2015) from recent $\mathrm{KE}$ literature, the mobile phone penetration or independent indicator of interest is proxied with the mobile phone penetration rate (per 100 people). Consistent with the narrative in Section 2, the six governance indicators from Kaufmann et al. (2010) are adopted as dependent variables. These are subsequently bundled into four governance composite indicators by means of principal component analysis (PCA) in Section 3.2.1. Accordingly, the underlying six governance dynamics are: the rule of law, corruption-control, regulation quality, government effectiveness, political stability/no violence and voice and accountability. The literature justifying the choice of underlying governance variables has been discussed in Section 2.

Three of the four pillars of the World Bank's Knowledge Economy Index (KEI) are used as knowledge diffusion variables, notably: education, innovation and ICT. First, education is measured with the 'pupil-teacher ratio' in primary education. The choice of this 
indicator is motivated by constraints in data availability and the comparative importance of primary education. It is important to note that we have been confronted with substantial issues in degrees of freedom with regards to other educational quality indicators like the 'pupil-teacher ratio in secondary education'. Moreover, relative to other levels of education, more positive development externalities have been documented to derive from primary education when countries are at initial stages of industrialisation. In essence, Petrakis and Stamatakis (2002) and Asiedu (2014) have argued that, compared to other levels of education, the underlying form of education is linked to higher social returns in undeveloped/developing countries.

Second, consistent with Tchamyou (2015), issues in degrees of freedom for innovation indicators like patent and trademark applications, motivate the study to use the number Scientific and Technical Journal Articles (STJA) published annually as a proxy for innovation. Third, in accordance with the motivation provided in the introduction from Penard et al. (2012), the study uses internet penetration as a complementary ICT indicator because of a high development potential in the sub-region.

Adopted variables of control are: foreign aid, foreign direct investment (FDI), population growth and economic growth. First, while financial globalisation has been documented by Lalountas et al. (2011) to reduce corruption in developing countries, the effect is open to debate when other governance indicators come into play. Second, the impact of foreign aid on governance is also debatable. While Okada and Samreth (2012) have established a negative nexus with corruption in developing countries, Asongu and Nwachukwu (2015b) have concluded on negative causalities between foreign aid and the six good governance indicators from Kaufmann et al. (2010). Third, population growth and economic growth have recently been employed by Asongu and Nwachukwu (2015a) in predicting the Arab Spring based on negative governance signals. A positive nexus between these indicators may be expected because income-levels are linked to higher governance standards and with a growing population, more government resources are expected to be devoted to serving and managing the population. On a cautious note, it is also important to balance this intuition with the fact that positive demographic change could also impede the government's ability to manage a growing population effectively.

Appendix 1 presents the definition of variables and their corresponding sources. The summary statistics is disclosed in Appendix 2 whereas Appendix 3 presents the correlation matrix. Based on the information provided by the summary statistics, it is apparent that: (i) 
means of the variables are comparable and (ii) from the corresponding standard deviations, we can be confident that reasonable estimated nexuses would emerge. The objective of the correlation matrix is to mitigate potential issues of multicollinearity that could significantly bias estimated coefficients. From a preliminary assessment, the high degree of substitution among governance indicators is apparent. In accordance with the discourse in Section 2 on the imperative to unbundle and bundle governance dynamics, conceptual priority takes precedence over degrees of substitution. Moreover, the issue of multicollinearity is not of nature to bias estimated coefficients because the governance indicators are used exclusively as dependent variables in distinct specifications.

\subsection{Methodology}

\subsubsection{Principal Component Analysis (PCA)}

The study employs PCA to bundle the six governance indicators from Kaufmann et al. (2010) into four composite indicators, namely; institutional, political, economic and general governances. This technique is in accordance with Asongu and Nwachukwu (2015a) from recent African institutional literature. The PCA is a statistical method that is employed to reduce a large set of highly correlated variables into a smaller set of uncorrelated indicators called principal components (PCs). These PCs represent a considerable variation or information in the original dataset. In this light, the six governance indicators are reduced to one common factor or general governance. The derived governance variable is a composite indicator with three-sub composite indicators, namely: political governance (consisting of political stability and voice \& accountability); economic governance (entailing government effectiveness and regulation quality) and institutional governance (encompassing the rule of law and corruption-control). Political governance is defined as the election and replacement of political leaders. Economic governance is the formulation and implementation of policies that deliver public commodities. Institutional governance is the respect of the State and citizens of institutions that govern interactions between them.

The Kaiser (1974) and Jolliffe (2002) criterion is used to retain common factors. According to the authors, only common factors with an eigenvalue greater than one or the mean should be retained. It is apparent from Table 1 that General governance (G.Gov) which accounts for more than $81 \%$ of information in the six governance indicators has an eigenvalue of 4.892. In the same perspective, institutional governance (Instgov), economic governance 
(Ecogov) and political governance (Polgov) have total variations (eigenvalues) of 93.0\%, $93.9 \%$ and $83.5 \%(1.861,1.878$ and 1.671$)$ respectively.

Table 1: Principal Component Analysis (PCA) for Composite Governance

\begin{tabular}{|c|c|c|c|c|c|c|c|c|c|}
\hline \multirow{2}{*}{$\begin{array}{c}\text { Principal } \\
\text { Components }\end{array}$} & \multicolumn{6}{|c|}{ Component Matrix(Loadings) } & \multirow[t]{2}{*}{ Proportion } & \multirow{2}{*}{$\begin{array}{l}\text { Cumulative } \\
\text { Proportion }\end{array}$} & \multirow{2}{*}{$\begin{array}{l}\text { Eigen } \\
\text { Value } \\
\end{array}$} \\
\hline & VA & PS & RQ & GE & RL & $\mathrm{CC}$ & & & \\
\hline First PC (G.Gov) & 0.395 & 0.372 & 0.411 & 0.426 & 0.439 & 0.404 & 0.815 & 0.815 & 4.892 \\
\hline Second PC & -0.037 & 0.873 & -0.357 & -0.303 & 0.037 & -0.124 & 0.067 & 0.883 & 0.407 \\
\hline Third PC & 0.747 & -0.035 & 0.157 & -0.131 & -0.086 & -0.626 & 0.052 & 0.935 & 0.314 \\
\hline First PC (Polgov) & 0.707 & 0.707 & --- & --- & --- & --- & 0.835 & 0.835 & 1.671 \\
\hline Second PC & -0.707 & 0.707 & --- & --- & --- & --- & 0.164 & 1.000 & 0.328 \\
\hline First PC (Ecogov) & --- & --- & 0.707 & 0.707 & --- & --- & 0.939 & 0.939 & 1.878 \\
\hline Second PC & --- & --- & -0.707 & 0.707 & --- & --- & 0.060 & 1.000 & 0.121 \\
\hline First PC (Instgov) & --- & --- & --- & --- & 0.707 & 0.707 & 0.930 & 0.930 & 1.861 \\
\hline Second PC & --- & --- & --- & --- & -0.707 & 0.707 & 0.069 & 1.000 & 0.138 \\
\hline
\end{tabular}

P.C: Principal Component. VA: Voice \& Accountability. RL: Rule of Law. R.Q: Regulation Quality. GE: Government Effectiveness. PS: Political Stability. CC: Control of Corruption. G.Gov (General Governance): First PC of VA, PS, RQ, GE, RL \& CC. Polgov (Political Governance): First PC of VA \& PS. Ecogov (Economic Governance): First PC of RQ \& GE. Instgov (Institutional Governance): First PC of RL \& CC.

We briefly devote space to discussing a number of concerns that may be associated with variables obtained from other regressions. According to Asongu and Nwachukwu (2015a), the documented concerns are linked the efficiency and consistency of estimated coefficients as well as validity of corresponding inferences. Pagan (1984, p.242) had established that while two-step estimators are efficient and consistent, few valid inferences can be drawn. This caution is consistent with an interesting stream of literature on the subject, namely: Oxley and McAleer (1993), McKenzie and McAleer (1997), Ba and Ng (2006) and Westerlund and Urbain (2013a).

Putting the above concern into perspective, Westerlund and Urbain $(2012,2013 \mathrm{~b})$ are to the best of our knowledge authors that have addressed the inferential quality of PCaugmented variables in the literature. The authors build on a bulk of previous studies ( (Pesaran, 2006; Stock \& Watson, 2002; Bai, 2003; Bai, 2009; Greenaway-McGrevy et al., 2012) to establish that it is possible to engage normal inferences from PC augmented regressions if estimated coefficients converge to their true values at the rate $\sqrt{N T}$, (with $\mathrm{T}$ being the number of time series and $\mathrm{N}$ denoting cross-section observations). They have further articulated that for the underlying convergence to occur, $\mathrm{T}$ and $\mathrm{N}$ have to be sufficiently large. Unfortunately, as far as we know, the authors do not specify how 'large is large'. Within the specific context of this study, we are faced with two major concerns. First, $\mathrm{N}$ cannot be further increased because all existing 49 nations in SSA have been engaged. 
Second, extending $\mathrm{T}$ is at the risk of compromising the validity of specifications since it will result in instrument proliferation that will bias estimated results. In a nutshell, in our opinion, valid inferences are possible because Asongu and Nwachukwu (2015a) have recently concluded using the same governance indicators (though with lower $\mathrm{T}$ and $\mathrm{N}$ ) that inferences do not substantially differ whether bundled or unbundled governance variables are used.

\subsubsection{Estimation technique}

The estimation approach adopted by this study is the GMM technique. As documented in Asongu and De Moor (2015b), five main reasons motivate the choice of this technique. Whereas the first-two consists of requirements for adopting the estimation strategy, the lastthree constitute advantages associated with the estimation technique. First, the estimation procedure is a good fit because the dependent variables are persistent. As apparent in Appendix 4, the rule of thumb threshold (0.800) for persistence in the dependent variables is met because the lowest correlation coefficient between governance dynamics and their corresponding lagged values is 0.965 . Second, the number of years per country (T) is lower than the number of countries $(\mathrm{N})$. Therefore, the $\mathrm{T}(12)<\mathrm{N}(49)$ condition for GMM application is also satisfied. Third, the estimation technique controls for potential endogeneity in all regressors. Fourth, cross-country variations are not eliminated with the approach. Fifth, it is on the basis of the fourth advantage that the Bond et al. (2001, pp. 3-4) have recommended that the system GMM estimator (Arellano \& Bover, 1995; Blundell \& Bond, 1998) is a better fit compared to the difference estimator from Arellano and Bond (1991).

In this study, we adopt the Roodman (2009ab) extension of Arellano and Bover (1995) which uses forward orthogonal deviations in place of first differences. The estimation approach has been documented to: (i) control for cross-country dependence and (ii) limit the proliferation of instruments or restrict over-identification (see Love \& Zicchino, 2006; Baltagi, 2008). A two-step approach is adopted in the specification because it controls for heteroscedasticity. Accordingly, the one-step approach is consistent with homoscedasticity.

The following equations in levels (1) and first difference (2) summarize the standard system GMM estimation procedure.

$$
G_{i, t}=\sigma_{0}+\sigma_{1} G_{i, t-\tau}+\sigma_{2} M_{i, t}+\sigma_{3} K_{i, t}+\sigma_{4} M K_{i, t}+\sum_{h=1}^{4} \delta_{h} W_{h, i, t-\tau}+\eta_{i}+\xi_{t}+\varepsilon_{i, t}
$$




$$
\begin{aligned}
G_{i, t}-G_{i, t-\tau} & =\sigma_{0}+\sigma_{1}\left(G_{i, t-\tau}-G_{i, t-2 \tau}\right)+\sigma_{2}\left(M_{i, t}-M_{i, t-\tau}\right)+\sigma_{3}\left(K_{i, t}-K_{i, t-\tau}\right)+\sigma_{3}\left(M K_{i, t}-M K_{i, t-\tau}\right) \\
& +\sum_{h=1}^{4} \delta_{h}\left(W_{h, i, t-\tau}-W_{h, i, t-2 \tau}\right)+\left(\xi_{t}-\xi_{t-\tau}\right)+\varepsilon_{i, t-\tau}
\end{aligned}
$$

Where: $G_{i, t}$ is a governance indicator (political, economic or institutional governance) of country $i$ at period $t ; \alpha$ is a constant; $\tau$ represents tau; $M$, Mobile phone penetration; $K$, denotes knowledge diffusion variables (educational quality, innovation and internet penetration); $W$ is the vector of control variables (GDP growth, population growth, foreign investment, and foreign aid), $\eta_{i}$ is the country-specific effect, $\xi_{t}$ is the time-specific constant and $\varepsilon_{i, t}$ the error term.

Given that the estimation technique being employed consists of using interactive regressions, it is relevant to briefly discuss some pitfalls associated with interactive regressions that have been documented by Brambor et al. (2006). According to the authors, all constitutive variables should be involved in the specifications. Moreover, for the estimated parameters to make economic sense, they should be interpreted as conditional marginal impacts.

\section{Empirical results}

In accordance with mainstream literature on GMM application, four main information criteria are employed to assess estimated models (see Asongu \& De Moor, 2015b). First, the null hypothesis of the second-order Arellano and Bond autocorrelation test $(\operatorname{AR}(2))$ in difference which stands for the absence of autocorrelation in the residuals should not be rejected. Second, conversely, the alternative hypotheses of the Sargan and Hansen overidentification restrictions (OIR) tests should be rejected because their null hypotheses are the positions that instruments are valid or not correlated with the error terms. In essence, the Hansen (Sargan) OIR test is robust (not robust) but weakened (not weakened) by instruments. Accordingly, for the purpose of limiting instrument proliferation, we have ensured that the rule of thumb requirement for restricting over-identification is met, notably: for each specification, the number of countries is higher than the number of instruments. Moreover, the validity of the Hansen OIR test is further assessed with the Difference in Hansen Test (DHT) for exogeneity of instruments. Fourth, the Fisher test is also provided to examine to the joint validity of estimated coefficients. 
Tables 2, 3, 4 and 5 present findings related to linkages between 'mobile phones, the diffusion of knowledge' and respectively 'political governance', 'economic governance', 'institutional governance' and 'general governance'. The following findings can be established from Table 2. First, we the exception of specifications pertaining to political governance, the unconditional effect of mobile phone is positive on political stability and 'voice and accountability'. Second, interactions between mobile phones and: (i) internet penetration has positive marginal effects on political stability and political governance and (ii) innovation has negative marginal effects on 'voice and accountability' and political governance. Third, with exceptions of the interactions associated with internet and mobile phone penetrations which are negative, other corresponding net effects are positive ${ }^{3}$. Fourth, with the exception of the last specification pertaining to political governance, the governance dynamics are stationary and converging because the absolute values of corresponding lagged endogenous variables is between 0 and $1^{4}$. The economic implication of convergence is that countries with lower levels of governance are catching-up their counterparts with higher governance standards. Fifth, most of the significant control variables have expected signs.

The following findings can be established from Table 3. First, the effect of mobile phones is consistently positive on economic governance and its constituents. Second, marginal effects corresponding to interactions with innovation are consistently negative while those corresponding to interactions with internet penetration are positive, with the exception of 'regulation quality'-oriented regressions. Unfortunately, valid inferences cannot be established from the highlighted regressions pertaining to economic governance because of post-estimation presence of second-order autocorrelation in residuals. Third, net effects associated with the three remaining valid specifications related to 'regulation quality' and 'government effectiveness' are positive. Fourth, evidence of convergence is also consistently apparent. Fifth, most of the significant control variables display expected signs.

\footnotetext{
3 For example, the net effect from the interaction between mobile phones and innovation on 'voice and accountability' is $0.0009([-0.000001 \times 91.231]+0.001)$. Where: 91.231 is the mean value of innovation (STJA).

${ }^{4}$ The interested reader can find more insights into the criterion for convergence and corresponding computation of the implied rate of convergence in Asongu (2014).
} 


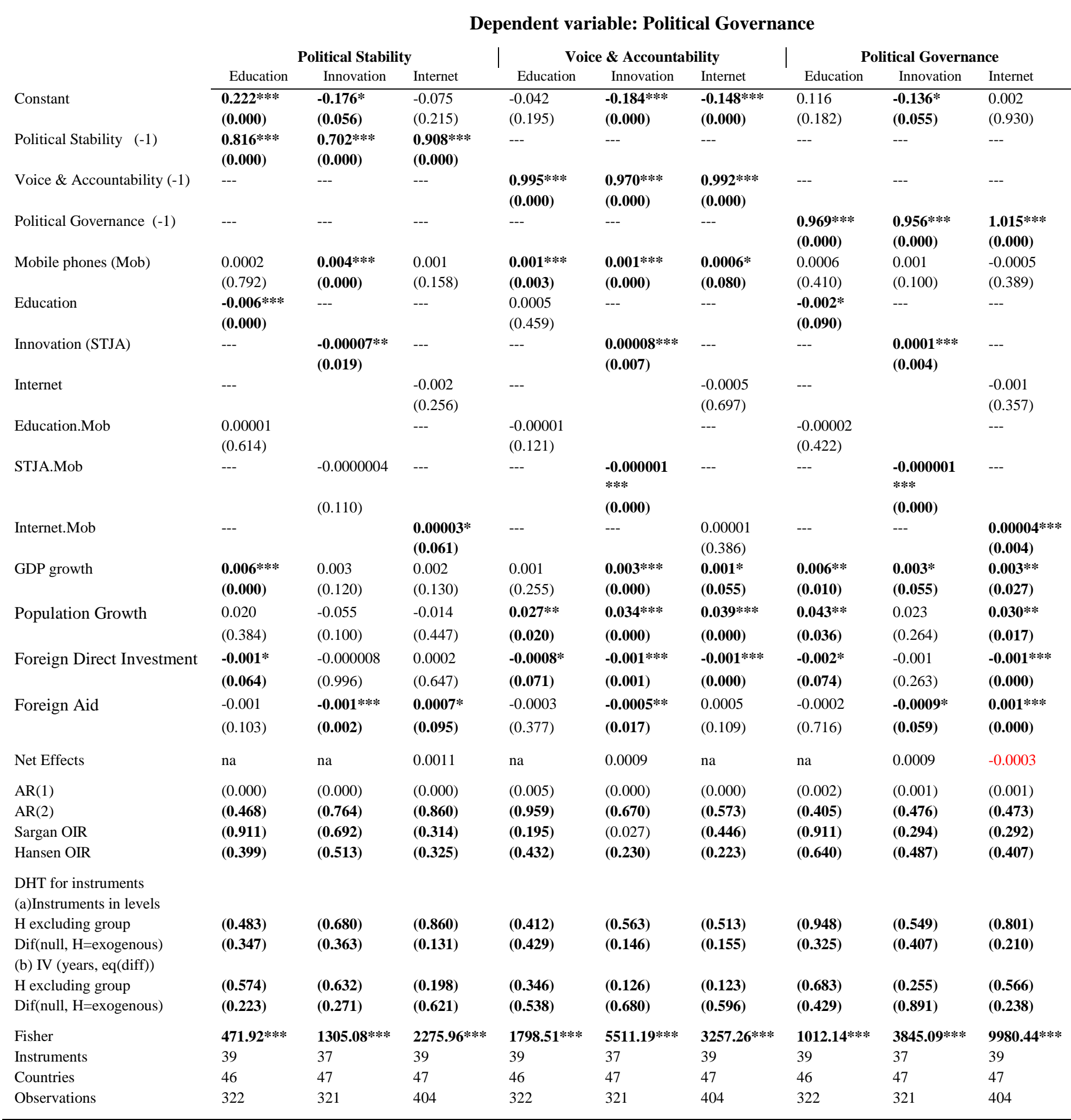

*,**,***: significance levels of 10\%, 5\% and 1\% respectively. STJA: Scientific and Technical Journal Articles. DHT: Difference in Hansen Test for Exogeneity of Instruments' Subsets. Dif: Difference. OIR: Over-identifying Restrictions Test. The significance of bold values is twofold. 1) The significance of estimated coefficients and the Fisher statistics. 2) The failure to reject the null hypotheses of: a) no autocorrelation in the $\operatorname{AR}(1)$ and $\operatorname{AR}(2)$ tests and; b) the validity of the instruments in the Sargan OIR test. na: not applicable due to the insignificance of marginal effects. 
Dependent variable: Economic Governance

\begin{tabular}{|c|c|c|c|c|c|c|c|c|c|}
\hline & Education & Innovation & Internet & Education & Innovation & Internet & Education & Innovation & Internet \\
\hline Constant & $\begin{array}{l}-0.090 * \\
(0.074)\end{array}$ & $\begin{array}{l}-0.209 * * * \\
(0.000)\end{array}$ & $\begin{array}{l}-0.101 * * * \\
(0.001)\end{array}$ & $\begin{array}{l}-0.073 * * \\
(0.022)\end{array}$ & $\begin{array}{l}-0.402 * * * \\
(0.000)\end{array}$ & $\begin{array}{l}-0.202 * * * \\
(0.000)\end{array}$ & $\begin{array}{l}-0.033 \\
(0.561)\end{array}$ & $\begin{array}{l}-0.360 * * * \\
(0.000)\end{array}$ & $\begin{array}{l}-0.093 * * \\
(0.044)\end{array}$ \\
\hline Government Effectiveness (-1) & $\begin{array}{l}0.889 * * * \\
(0.000)\end{array}$ & $\begin{array}{l}0.886 * * * \\
(0.000)\end{array}$ & $\begin{array}{l}0.895 * * * \\
(0.000)\end{array}$ & --- & --- & --- & --- & --- & --- \\
\hline Regulation Quality (-1) & --- & --- & --- & $\begin{array}{l}0.909 * * * \\
(0.000)\end{array}$ & $\begin{array}{l}0.807 * * * \\
(0.000)\end{array}$ & $\begin{array}{l}0.864 * * * \\
(0.000)\end{array}$ & --- & --- & --- \\
\hline Economic Governance $(-1)$ & --- & --- & --- & --- & --- & --- & $\begin{array}{l}0.928 * * * \\
(0.000)\end{array}$ & $\begin{array}{l}0.866 * * * \\
(0.000)\end{array}$ & $\begin{array}{l}0.929 * * * \\
(0.000)\end{array}$ \\
\hline Mobile phones (Mob) & $\begin{array}{l}0.001 * * * \\
(0.001)\end{array}$ & $\begin{array}{l}0.001 * * * \\
(0.003)\end{array}$ & $\begin{array}{l}0.0007 * * * \\
(0.001)\end{array}$ & $\begin{array}{l}0.0004 \\
(0.120)\end{array}$ & $\begin{array}{l}0.003 * * * \\
(0.000)\end{array}$ & $\begin{array}{l}0.001 * * * \\
(0.000)\end{array}$ & $\begin{array}{l}0.002 * * * \\
(0.000)\end{array}$ & $\begin{array}{l}0.004 * * * \\
(0.000)\end{array}$ & $\begin{array}{l}0.001 * * \\
(0.014)\end{array}$ \\
\hline Education & $\begin{array}{l}-0.0007 \\
(0.244)\end{array}$ & --- & --- & $\begin{array}{l}-0.0008 \\
(0.160)\end{array}$ & --- & --- & $\begin{array}{l}-0.001 \\
(0.333)\end{array}$ & --- & --- \\
\hline Innovation (STJA) & -- & $\begin{array}{l}0.0001 * * * \\
(0.000)\end{array}$ & --- & --- & $\begin{array}{l}0.0002 * * * \\
(0.000)\end{array}$ & --- & & $\begin{array}{l}0.0005 * * * \\
(0.000)\end{array}$ & --- \\
\hline Internet & --- & --- & $\begin{array}{l}-0.001 \\
(0.234)\end{array}$ & --- & & $\begin{array}{l}0.002 \\
(0.180)\end{array}$ & & & $\begin{array}{l}-0.001 \\
(0.644)\end{array}$ \\
\hline Education.Mob & $\begin{array}{l}-0.00001 \\
(0.258)\end{array}$ & --- & --- & $\begin{array}{l}0.00001 \\
(0.283)\end{array}$ & & --- & $\begin{array}{l}-0.000008 \\
(0.611)\end{array}$ & & --- \\
\hline STJA.Mob & --- & $\begin{array}{l}-\mathbf{0 . 0 0 0 0 0 1} \\
* * * \\
(\mathbf{0 . 0 0 0 )}\end{array}$ & --- & --- & $\begin{array}{l}-\mathbf{0 . 0 0 0 0 0 2} \\
* * * \\
(\mathbf{0 . 0 0 0 )}\end{array}$ & --- & --- & $\begin{array}{l}\mathbf{- 0 . 0 0 0 0 0 5} \\
* * * \\
(\mathbf{0 . 0 0 0 )}\end{array}$ & --- \\
\hline Internet.Mob & --- & --- & $\begin{array}{l}0.00002 * * * \\
(0.008)\end{array}$ & --- & --- & $\begin{array}{l}-0.00001 \\
(0.230)\end{array}$ & --- & --- & $\begin{array}{l}0.00004 * * \\
(0.029)\end{array}$ \\
\hline GDP growth & $\begin{array}{l}0.003 * * * \\
(0.001)\end{array}$ & $\begin{array}{l}0.003 * * * \\
(0.000)\end{array}$ & $\begin{array}{l}0.002 * * * \\
(0.000)\end{array}$ & $\begin{array}{l}-0.0001 \\
(0.890)\end{array}$ & $\begin{array}{l}0.0001 \\
(0.789)\end{array}$ & $\begin{array}{l}0.0006 \\
(0.253)\end{array}$ & $\begin{array}{l}0.002 \\
(0.258)\end{array}$ & $\begin{array}{l}0.001 \\
(0.222)\end{array}$ & $\begin{array}{l}0.002 * * \\
(0.013)\end{array}$ \\
\hline Population Growth & $\begin{array}{l}0.025 * \\
(0.088)\end{array}$ & $\begin{array}{l}0.019 \\
(0.129)\end{array}$ & $\begin{array}{l}-0.010 \\
(0.309)\end{array}$ & $\begin{array}{l}0.016 * \\
(0.080)\end{array}$ & $\begin{array}{l}0.064 * * * \\
(0.000)\end{array}$ & $\begin{array}{l}0.006 \\
(0.238)\end{array}$ & $\begin{array}{l}0.058 * * \\
(0.014)\end{array}$ & $\begin{array}{l}\text { 0.108**** } \\
(0.000)\end{array}$ & $\begin{array}{l}0.009 \\
(0.503)\end{array}$ \\
\hline Foreign Direct Investment & $\begin{array}{l}-0.001 * * * \\
(0.001)\end{array}$ & $\begin{array}{l}0.002 * * * \\
(0.000)\end{array}$ & $\begin{array}{l}0.001 * * * \\
(0.002)\end{array}$ & $\begin{array}{l}-0.0006 \\
(0.145)\end{array}$ & $\begin{array}{l}0.003 * * * \\
(0.000)\end{array}$ & $\begin{array}{l}0.001 * * * \\
(0.000)\end{array}$ & $\begin{array}{l}-0.001 * * \\
(0.028)\end{array}$ & $\begin{array}{l}0.008 * * * \\
(0.000)\end{array}$ & $\begin{array}{l}\mathbf{0 . 0 0 3} * * * \\
(0.000)\end{array}$ \\
\hline Foreign Aid & $\begin{array}{l}-0.001 \\
(0.207)\end{array}$ & $\begin{array}{l}-0.0005^{*} \\
(0.068)\end{array}$ & $\begin{array}{l}0.0002 \\
(0.390)\end{array}$ & $\begin{array}{l}-0.001 * * * \\
(0.004)\end{array}$ & $\begin{array}{l}-0.001 * * * \\
(0.000)\end{array}$ & $\begin{array}{l}-0.0008 * * * \\
(0.007)\end{array}$ & $\begin{array}{l}-0.001 * \\
(0.088)\end{array}$ & $\begin{array}{l}-0.0008 \\
(0.174)\end{array}$ & $\begin{array}{l}0.00003 \\
(0.937)\end{array}$ \\
\hline Net Effects & na & 0.0009 & 0.0007 & na & 0.0028 & na & na & 0.0035 & 0.0011 \\
\hline $\mathrm{AR}(1)$ & $(0.003)$ & $(0.000)$ & $(0.000)$ & $(0.007)$ & $(0.013)$ & $(0.014)$ & $(0.000)$ & $(0.001)$ & $(0.000)$ \\
\hline $\mathrm{AR}(2)$ & $(0.244)$ & (0.298) & $(0.202)$ & $(0.094)$ & $(0.124)$ & (0.149) & (0.160) & $(0.082)$ & $(0.039)$ \\
\hline Sargan OIR & $(0.365)$ & $(0.703)$ & $(0.670)$ & $(0.000)$ & $(0.001)$ & $(0.000)$ & $(0.045)$ & $(0.386)$ & $(0.074)$ \\
\hline Hansen OIR & $(0.476)$ & $(0.463)$ & $(0.552)$ & $(0.290)$ & $(0.316)$ & $(0.346)$ & (0.179) & $(0.679)$ & $(0.486)$ \\
\hline $\begin{array}{l}\text { DHT for instruments } \\
\text { (a)Instruments in levels }\end{array}$ & & & & & & & & & \\
\hline $\mathrm{H}$ excluding group & $(0.893)$ & $(0.418)$ & $(0.536)$ & $(0.364)$ & $(0.460)$ & $(0.728)$ & $(0.402)$ & (0.977) & $(0.812)$ \\
\hline $\begin{array}{l}\text { Dif(null, H=exogenous) } \\
\text { (b) IV (years, eq(diff)) }\end{array}$ & $(0.222)$ & $(0.463)$ & $(0.490)$ & $(0.290)$ & $(0.268)$ & (0.189) & (0.149) & $(0.331)$ & $(0.271)$ \\
\hline $\mathrm{H}$ excluding group & (0.449) & $(0.421)$ & $(0.258)$ & $(0.240)$ & (0.119) & $(0.164)$ & $(0.057)$ & $(0.597)$ & $(0.266)$ \\
\hline Dif(null, $\mathrm{H}=$ exogenous) & $(0.461)$ & $(0.485)$ & $(0.897)$ & $(0.449)$ & $(0.937)$ & $(0.757)$ & $(0.792)$ & $(0.618)$ & $(0.784)$ \\
\hline Fisher & $1889.18 * * *$ & $5159.88 * * *$ & $3053.36^{* * * *}$ & $2995.56 * * *$ & $15671.8^{* * * *}$ & $1192.88 * * *$ & $\mathbf{5 0 8 1 . 5 6}^{* * *}$ & $12695.4 * * *$ & $6100.15 * * *$ \\
\hline Instruments & 39 & 37 & 39 & 39 & 37 & 39 & 39 & 37 & 39 \\
\hline Countries & 46 & 47 & 47 & 46 & 47 & 47 & 46 & 47 & 47 \\
\hline Observations & 322 & 321 & 404 & 322 & 321 & 404 & 322 & 321 & 404 \\
\hline
\end{tabular}

*,**,***: significance levels of 10\%, 5\% and 1\% respectively. STJA: Scientific and Technical Journal Articles. DHT: Difference in Hansen Test for Exogeneity of Instruments' Subsets. Dif: Difference. OIR: Over-identifying Restrictions Test. The significance of bold values is twofold. 1) The significance of estimated coefficients and the Fisher statistics. 2) The failure to reject the null hypotheses of: a) no autocorrelation in the $\operatorname{AR}(1)$ and $\operatorname{AR}(2)$ tests and; b) the validity of the instruments in the Sargan OIR test. na: not applicable due to the insignificance of marginal effects. 
Constant

Rule of Law (-1)

Corruption Control (-1)

Institutional Governance $(-1)$

Mobile phones (Mob)

Education

Innovation (STJA)

Internet

Education.Mob

STJA.Mob

Internet.Mob

GDP growth

Population Growth

Foreign Direct Investment

Foreign Aid

Net Effects

$\operatorname{AR}(1)$

$\operatorname{AR}(2)$

Sargan OIR

Hansen OIR

DHT for instruments

(a)Instruments in levels

$\mathrm{H}$ excluding group

Dif(null, $\mathrm{H}=$ exogenous)

(b) IV (years, eq(diff))

$\mathrm{H}$ excluding group

Dif(null, H=exogenous)

Fisher

Instruments

Countries

Observations

Dependent variable: Institutional Governance

\begin{tabular}{|c|c|c|c|c|c|c|c|c|}
\hline \multicolumn{3}{|c|}{ Rule of Law } & \multicolumn{3}{|c|}{ Corruption Control } & \multicolumn{3}{|c|}{ Institutional Governance } \\
\hline Education & Innovation & Internet & Education & Innovation & Internet & Education & Innovation & Intern \\
\hline$-0.101 * *$ & $-0.216 * * *$ & $-0.106 * * *$ & 0.044 & $-0.157 * * *$ & -0.062 & -0.089 & $-0.273 * * *$ & -0.06 \\
\hline$(0.014)$ & $(0.000)$ & $(0.001)$ & $(0.352)$ & $(0.000)$ & $(0.161)$ & $(0.306)$ & $(0.001)$ & $(0.22$ \\
\hline $0.956 * * *$ & $0.937 * * *$ & $0.943 * * *$ & --- & --- & --- & --- & --- & --- \\
\hline$(0.000)$ & $(0.000)$ & $(0.000)$ & & & & & & \\
\hline --- & --- & --- & $0.826 * * *$ & $0.841 * * *$ & $0.894 * * *$ & --- & --- & --- \\
\hline
\end{tabular}

$\begin{array}{llll}(0.000) & (0.000) & (0.000)\end{array}$

$\begin{array}{lll}--- & -- & -- \\ 0.001 * * & 0.0008 * & 0.00 \\ (0.020) & (0.080) & (0.2 \\ -0.001 * & -- & -- \\ (0.066) & & \\ -- & \mathbf{0 . 0 0 0 1} * * * \\ & (0.000) & \end{array}$

--- ---

$--$

\subsection{3}

\subsection{5}

$0.001 * *$

$0.940 * * *$

$(0.000)$

$0.895 * * * \quad 0.947 * * *$

\section{$(0.239)$ \\ $(0.232)$}

(0.028)

$0.0009 * *$

$0.001 * *$

(0.000)

(0.000)

$-0.002 * * *$

---

(0.047)

(0.016)

(0.003)

0.0002

$-0.001$

(0.328)

$-0.00002 * *$

(0.029)

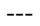

$-0.000001$

$* * *$

(0.000)

(0.000)

0.002*

(0.065)

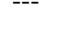

$---$

0.00001

(0.354)

$$
\text { --- --- }
$$

(0.000)

$-0.000006$

(0.400)

\section{$0.002 * *$}

(0.010)

$0.057 * * *$

(0.000)

$\mathbf{- 0 . 0 0 0 6 * *}$

(0.025)

-0.0008 **

(0.040)

0.0001

(0.006)

(0.212)

(0.585)

(0.334)

\section{$-0.001 * *$}

0.0001

(0.038)

(0.748)

0.068***

0.016**

(0.000)

(0.030)

$0.001 * * *$

$0.001 * * *$

(0.003)

(0.000)

$-0.001 * * *$

$-0.0003$

(0.001)

(0.105)

0.0007

$$
\text { (0.000) }
$$

(0.745)

na

(0.330)

(0.343)

(0.156)

(0.159)

$(\mathbf{0 . 3 6 7})$
$(\mathbf{0 . 3 4 2})$
$(\mathbf{0 . 5 1 0})$
$(\mathbf{0 . 1 9 9 )}$
$\mathbf{9 2 2 . 4 0 * * *}$
39
46
322

$\begin{array}{ll}\mathbf{( 0 . 1 1 2 )} & \mathbf{( 0 . 3 1 6 )} \\ \mathbf{( 0 . 3 2 2 )} & (\mathbf{0 . 1 6 0 )} \\ & \\ (\mathbf{0 . 4 9 7 )} & \mathbf{( 0 . 0 7 8 )} \\ \mathbf{( 0 . 0 4 0 )} & (\mathbf{0 . 5 9 2 )} \\ \mathbf{3 7 4 6 . 8 3}^{* * * *} & \mathbf{1 3 5 4 . 5 2} * * * \\ 37 & 39 \\ 47 & 47 \\ 321 & 404\end{array}$

$\mathbf{- 0 . 0 0 2} * * *$
$(\mathbf{0 . 0 0 3})$
-0.018
$(0.354)$
$\mathbf{- 0 . 0 0 1} * * *$
$(\mathbf{0 . 0 0 1})$
0.0005
$(0.131)$
na
$(0.001)$
$(\mathbf{0 . 3 9 4})$
$(\mathbf{0 . 4 3 4 )}$
$(\mathbf{0 . 1 5 4 )}$

$(\mathbf{0 . 7 4 2})$
$(\mathbf{0 . 0 5 9})$
$(\mathbf{0 . 3 0 9})$
$(\mathbf{0 . 1 2 6})$
$\mathbf{7 1 3 . 2 1} * * *$
39
46
322

---

(0.002)

0.001

(0.942)

0.0009

(0.144)

(0.658)

0.0008

(0.000)

(0.410)

(0.798)

(0.106) $0.00002 * *$

(0.002)

-0.002 ***

-0.001 *

(0.061)

-0.023 **

(0.013)

0.0003

(0.254)

0.0003

(0.379)

0.0008

(0.000)

(0.350)

(0.971)

(0.675)

$(\mathbf{0 . 5 3 1 )}$
$(\mathbf{0 . 0 5 8 )}$

$\mathbf{( 0 . 2 4 5 )}$
$(\mathbf{0 . 0 8 6 )}$
$\mathbf{3 4 9 9 . 9 6 * * *}$
37
47
321

$\mathbf{( 0 . 6 6 7 )}$
$(\mathbf{0 . 5 5 8 )}$
$(\mathbf{0 . 6 1 4 )}$
$(\mathbf{0 . 5 7 9 )}$
$\mathbf{2 6 1 9 . 2 9 * * *}$
39
47
404

(0.525)

(0.357)

(0.604)

$-0.000002$

(0.894)

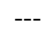

$-0.000004$

****

(0.000)

$0.0004 * * *$

(0.000)

0.003

(0.102)

$---$

$-0.00002$

(0.157)

-0.002 *

(0.084)

0.013

0.043*

$0.069 * * *$

(0.434)

0.001***

$0.0009 * \quad 0.002$

(0.007)

$-0.000001$

(0.997)

na

$(0.001)$

(0.179)

(0.959)

(0.807)

***,***: significance levels of 10\%, 5\% and 1\% respectively. STJA: Scientific and Technical Journal Articles. DHT: Difference in Hansen Test for Exogeneity of Instruments' Subsets. Dif: Difference. OIR: Over-identifying Restrictions Test. The significance of bold values is twofold. 1) The significance of estimated coefficients and the Fisher statistics. 2) The failure to reject the null hypotheses of: a) no autocorrelation in the $\operatorname{AR}(1)$ and $\operatorname{AR}(2)$ tests and; b) the validity of the instruments in the Sargan OIR test. na: not applicable due to the insignificance of marginal effects. 
Table 5: The mobile phone, knowledge diffusion and general governance

\begin{tabular}{|c|c|c|c|}
\hline & \multicolumn{3}{|c|}{ Dependent variable: General Governance } \\
\hline & Education & Innovation & Internet \\
\hline \multirow[t]{2}{*}{ Constant } & -0.119 & $-0.346 * * *$ & -0.072 \\
\hline & $(0.217)$ & $(0.000)$ & $(0.306)$ \\
\hline \multirow[t]{2}{*}{ General Governance $\quad(-1)$} & $0.968 * * *$ & $0.961 * * *$ & $1.033 * * *$ \\
\hline & $(0.000)$ & $(0.000)$ & $(\mathbf{0 . 0 0 0})$ \\
\hline \multirow[t]{2}{*}{ Mobile phones (Mob) } & $\mathbf{0 . 0 0 3} * * *$ & $0.002 * *$ & -0.001 \\
\hline & $(0.000)$ & $(0.018)$ & $(0.201)$ \\
\hline \multirow[t]{2}{*}{ Education } & 0.0001 & --- & --- \\
\hline & $(0.910)$ & & \\
\hline \multirow[t]{2}{*}{ Innovation (STJA) } & --- & $0.0005 * * *$ & --- \\
\hline & & $(0.000)$ & \\
\hline \multirow[t]{2}{*}{ Internet } & --- & --- & $-0.009 * * *$ \\
\hline & & & $(0.001)$ \\
\hline \multirow[t]{2}{*}{ Education.Mob } & -0.00003 & --- & --- \\
\hline & $(0.125)$ & & \\
\hline \multirow[t]{2}{*}{ STJA.Mob } & --- & $-0.000006 * * *$ & --- \\
\hline & & $(0.000)$ & \\
\hline \multirow[t]{2}{*}{ Internet.Mob } & --- & --- & $0.0001 * * *$ \\
\hline & & & $(0.000)$ \\
\hline \multirow[t]{2}{*}{ GDP growth } & $0.003 *$ & 0.002 & -0.0008 \\
\hline & $(0.078)$ & $(0.319)$ & $(0.615)$ \\
\hline \multirow[t]{2}{*}{ Population Growth } & $\mathbf{0 . 0 8 0} * * *$ & $0.101 * * *$ & $0.065 * * *$ \\
\hline & $(0.003)$ & $(0.001)$ & $(0.007)$ \\
\hline \multirow[t]{2}{*}{ Foreign Direct Investment } & $-0.002 * *$ & 0.002 & 0.0003 \\
\hline & $(0.015)$ & $(0.105)$ & $(0.542)$ \\
\hline \multirow[t]{2}{*}{ Foreign Aid } & -0.0006 & -0.0008 & 0.001 \\
\hline & $(0.697)$ & $(0.231)$ & $(0.008)$ \\
\hline Net Effects & na & 0.1452 & -0.0005 \\
\hline $\operatorname{AR}(1)$ & $(0.001)$ & $(0.000)$ & $(0.000)$ \\
\hline $\operatorname{AR}(2)$ & $(0.290)$ & $(0.205)$ & $(0.181)$ \\
\hline Sargan OIR & $(0.607)$ & $(0.764)$ & $(0.989)$ \\
\hline Hansen OIR & $(0.426)$ & $(0.379)$ & $(0.495)$ \\
\hline \multicolumn{4}{|l|}{$\begin{array}{l}\text { DHT for instruments } \\
\text { (a)Instruments in levels }\end{array}$} \\
\hline $\mathrm{H}$ excluding group & $(0.432)$ & $(0.322)$ & $(0.587)$ \\
\hline Dif(null, $\mathrm{H}=$ exogenous) & $(0.408)$ & $(0.431)$ & $(0.394)$ \\
\hline (b) IV (years, eq(diff)) & $(0.290)$ & $(0.534)$ & $(0.246)$ \\
\hline $\mathrm{H}$ excluding group & $(0.626)$ & $(0.201)$ & $(0.837)$ \\
\hline \multicolumn{4}{|l|}{ Dif(null, $\mathrm{H}=$ exogenous) } \\
\hline Fisher & $2261.22 * * *$ & $7270.26 * * *$ & $31108.08 * * *$ \\
\hline Instruments & 39 & 37 & 39 \\
\hline Countries & 46 & 47 & 47 \\
\hline Observations & 322 & 321 & 404 \\
\hline
\end{tabular}

***,***: significance levels of $10 \%, 5 \%$ and $1 \%$ respectively. STJA: Scientific and Technical Journal Articles. DHT: Difference in Hansen Test for Exogeneity of Instruments' Subsets. Dif: Difference. OIR: Over-identifying Restrictions Test. The significance of bold values is twofold. 1) The significance of estimated coefficients and the Fisher statistics. 2) The failure to reject the null hypotheses of: a) no autocorrelation in the AR(1) and AR(2) tests and; b) the validity of the instruments in the Sargan OIR test. na: not applicable due to the insignificance of marginal effects. 
From Table 4 on the relationships between mobile phone penetration, knowledge diffusion and institutional governance: (i) the unconditional effect of mobile phone penetration is consistently positive on institutional governance and its constituents; (ii) conditional or marginal effects from interactions with innovation are consistently negative and that associated with education (internet penetration) in 'the rule of law' (corruption-control) regressions is also negative; (iii) corresponding net effects are positive, with the highest magnitude in the innovation specification of 'institutional governance' regressions and (iv) most of the control variables are significant with excepted signs.

The findings from Table 5 pertaining to general governance are broadly consistent with those established in the preceding tables with corresponding marginal and net effects aligning with specifications on institutional governance in Table 2. With a thin exception from the last specification in Table 4, evidence of convergence is also consistently apparent in Tables 4-5.

\section{Concluding implications and further directions}

We set-out to assess the mobile phone in the diffusion of knowledge for better governance in sub-Saharan Africa for the period 2000-2012. For this purpose, we have employed a Generalised Method of Moments (GMM) with forward orthogonal deviations. The empirical evidence is based on three complementary knowledge diffusion variables (innovation, internet penetration and educational quality) and ten governance indicators that are bundled and unbundled. The following are some of the main findings. First, there is an unconditional positive effect of mobile phone penetration on good governance. Second, the net effects on political, economic and institutional governances, associated with the interaction of the mobile phone with knowledge diffusion variables are positive for the most part. Third countries with low levels of governance are catching-up their counterparts with higher levels of governance.

The above findings are broadly consistent with Snow (2009) who has assessed the relevance on mobile phones in mitigating corruption in Africa. The evidence of some insignificant net effects and decreasing marginal impacts may be an indication that the mobile phone could also be employed to decrease government quality. While this position is also sustained by Snow (2009), the author concludes that the negative effects are very likely to outweigh associated positive net effects on corruption. Overall, this study has established net 
positive effects for the most part. Five rationales could elicit the positive net effects on good governance from the interaction between mobile phones and knowledge diffusion, among others, the knowledge variables enhance: reach, access, adoption, cost-effectiveness and interaction. In a nut shell, the positive net effects are apparent because the knowledge diffusion variables complement mobile phones in reducing information asymmetry and monopoly that create conducive conditions for bad governance.

Whereas the established findings are consistent with the theoretical underpinnings discussed in Section 2, they also have other relevant theoretical contributions, notably: on information asymmetry and convergence. First, with regards to information asymmetry, the mobile telephony reduces information asymmetry through enhanced oversight by civil society, public officials and households. In essence, the evidence that mobile phones are positively (negatively) correlated with the informal (formal) economic sector (Asongu, 2013) is an indication that a great chunk of civil society that operates within informal politicoeconomic and social sectors can contribute towards improving government quality through the mobile phone. In essence, the mobile telephony enables the sharing of information that ultimately reduces information asymmetry by allocating resources more efficiently and minimising 'government cost'. The narrative is broadly in accordance with the paradigm of information sharing for reducing information asymmetry in financial institutions (see Claus \& Grimes, 2003). Hence, based on our findings the theoretical underpinnings of information asymmetry in financial institutions can be extended to government institutions.

Second, the findings have shown that past differences in government quality have a less proportionate impact on future differences in government quality. In this light the equations on the left-hand-side have been decreasing over time. The corresponding economic interpretation is that countries with lower levels of governance are catching-up their counterparts with higher governance levels. The finding contributes to the theoretical underpinnings of catch-up literature in the perspective that catch-up is beyond incomeconvergence (see Asongu, 2014) and can be extended from GDP per capita to other development outcomes. Asongu and Nwachukwu (2015a) have recently used catch-up in negative government signals to predict the 2011 Arab Spring. Overall, the findings established by this study are in accordance with the theoretical underpinnings of cross-country income convergence that have been substantially documented within the frameworks of neoclassical growth models (Solow, 1956; Swan, 1956; Baumol, 1986; Barro, 1991; Mankiw et al., 1992; Barro \& Sala-i-Martin, 1992, 1995; Fung, 2009) and currently being extended to 
other fields of economics and finance, inter alia: inclusive human development (MayerFoulkes, 2010); knowledge economy (Asongu, 2015b) and financial markets (Narayan et al., 2011; Bruno et al., 2012). Given the limited applicability of beta convergence techniques within country-specific settings, the findings leave room for extension with the sigma convergence approach for country-specific trends on government quality catch-up. 


\section{Appendices}

\section{Appendix 1: Variable Definitions}

\begin{tabular}{|c|c|c|c|}
\hline Variables & Signs & Variable Definitions (Measurements) & Sources \\
\hline Political Stability & PolSta & $\begin{array}{l}\text { "Political stability/no violence (estimate): measured as the } \\
\text { perceptions of the likelihood that the government will be } \\
\text { destabilized or overthrown by unconstitutional and violent } \\
\text { means, including domestic violence and terrorism" }\end{array}$ & World Bank (WDI) \\
\hline $\begin{array}{l}\text { Voice \& } \\
\text { Accountability }\end{array}$ & V\&A & $\begin{array}{l}\text { "Voice and accountability (estimate): measures the extent to } \\
\text { which a country's citizens are able to participate in selecting } \\
\text { their government and to enjoy freedom of expression, freedom } \\
\text { of association and a free media". }\end{array}$ & World Bank (WDI) \\
\hline $\begin{array}{l}\text { Political } \\
\text { Governance }\end{array}$ & Polgov & $\begin{array}{l}\text { First Principal Component of Political Stability and Voice \& } \\
\text { Accountability. The process by which those in authority are } \\
\text { selected and replaced. }\end{array}$ & PCA \\
\hline $\begin{array}{l}\text { Government } \\
\text { Effectiveness }\end{array}$ & Gov. E & $\begin{array}{l}\text { "Government effectiveness (estimate): measures the quality of } \\
\text { public services, the quality and degree of independence from } \\
\text { political pressures of the civil service, the quality of policy } \\
\text { formulation and implementation, and the credibility of } \\
\text { governments' commitments to such policies". }\end{array}$ & World Bank (WDI) \\
\hline $\begin{array}{l}\text { Regulation } \\
\text { Quality }\end{array}$ & RQ & $\begin{array}{l}\text { "Regulation quality (estimate): measured as the ability of the } \\
\text { government to formulate and implement sound policies and } \\
\text { regulations that permit and promote private sector } \\
\text { development". }\end{array}$ & World Bank (WDI) \\
\hline $\begin{array}{l}\text { Economic } \\
\text { Governance }\end{array}$ & Ecogov & $\begin{array}{l}\text { "First Principal Component of Government Effectiveness and } \\
\text { Regulation Quality. The capacity of government to formulate } \\
\text { \& implement policies, and to deliver services". }\end{array}$ & PCA \\
\hline Rule of Law & RL & $\begin{array}{l}\text { "Rule of law (estimate): captures perceptions of the extent to } \\
\text { which agents have confidence in and abide by the rules of } \\
\text { society and in particular the quality of contract enforcement, } \\
\text { property rights, the police, the courts, as well as the likelihood } \\
\text { of crime and violence". }\end{array}$ & World Bank (WDI) \\
\hline $\begin{array}{l}\text { Corruption- } \\
\text { Control }\end{array}$ & $\mathrm{CC}$ & $\begin{array}{l}\text { "Control of corruption (estimate): captures perceptions of the } \\
\text { extent to which public power is exercised for private gain, } \\
\text { including both petty and grand forms of corruption, as well as } \\
\text { 'capture' of the state by elites and private interests". }\end{array}$ & World Bank (WDI) \\
\hline $\begin{array}{l}\text { Institutional } \\
\text { Governance }\end{array}$ & Instgov & $\begin{array}{l}\text { First Principal Component of Rule of Law and Corruption- } \\
\text { Control. The respect for citizens and the state of institutions } \\
\text { that govern the interactions among them }\end{array}$ & PCA \\
\hline $\begin{array}{l}\text { General } \\
\text { Governance }\end{array}$ & G.gov & $\begin{array}{l}\text { First Principal Component of Political, Economic and } \\
\text { Institutional Governances }\end{array}$ & PCA \\
\hline Mobile phones & Mobile & Mobile phone subscriptions (per 100 people) & World Bank (WDI) \\
\hline $\begin{array}{l}\text { Educational } \\
\text { Quality }\end{array}$ & Educ & Pupil teacher ratio in Primary Education & World Bank (WDI) \\
\hline Innovation & STJA & Scientific and Technical Journal Articles & World Bank (WDI) \\
\hline Internet & Internet & Internet penetration (per 100 people) & World Bank (WDI) \\
\hline GDP growth & GDPg & Gross Domestic Product (GDP) growth (annual \%) & World Bank (WDI) \\
\hline Population growth & Popg & Population growth rate (annual \%) & World Bank (WDI) \\
\hline $\begin{array}{l}\text { Foreign } \\
\text { investment }\end{array}$ & FDI & Foreign Direct Investment inflows (\% of GDP) & World Bank (WDI) \\
\hline Foreign aid & Aid & Total Development Assistance (\% of GDP) & World Bank (WDI) \\
\hline
\end{tabular}

WDI: World Bank Development Indicators. PCA: Principal Component Analysis. 
Appendix 2: Summary statistics (2000-2012)

\begin{tabular}{|c|c|c|c|c|c|}
\hline & Mean & SD & Minimum & Maximum & Observations \\
\hline Political Stability & -0.543 & 0.956 & -3.323 & 1.192 & 578 \\
\hline Voice \& Accountability & -0.646 & 0.737 & -2.233 & 0.990 & 578 \\
\hline Political Governance & 0.000 & 1.292 & -3.440 & 2.583 & 578 \\
\hline Government Effectiveness & -0.771 & 0.620 & -2.450 & 0.934 & 577 \\
\hline Regulation Quality & -0.715 & 0.644 & -2.665 & 0.983 & 578 \\
\hline Economic Governance & 0.002 & 1.367 & -4.049 & 3.807 & 577 \\
\hline Rule of Law & 0.002 & 1.367 & -4.049 & 3.807 & 577 \\
\hline Control of Corruption & -0.642 & 0.591 & -1.924 & 1.249 & 579 \\
\hline Institutional Governance & 0.0002 & 1.364 & -3.588 & 3.766 & 578 \\
\hline General Governance & 0.004 & 2.210 & -6.308 & 5.561 & 577 \\
\hline Mobile phone penetration & 23.379 & 28.004 & 0.000 & 147.202 & 572 \\
\hline Educational Quality & 43.601 & 14.529 & 12.466 & 100.236 & 444 \\
\hline Innovation (STJA) & 91.231 & 360.522 & 0.000 & 2915.5 & 480 \\
\hline Internet Penetration & 4.152 & 6.450 & 0.005 & 43.605 & 566 \\
\hline GDP growth & 4.714 & 6.322 & -47.552 & 63.379 & 608 \\
\hline Population growth & 2.361 & 0.948 & -1.081 & 6.576 & 588 \\
\hline Foreign Direct Investment inflows & 5.332 & 8.737 & -6.043 & 91.007 & 603 \\
\hline Foreign aid & 11.687 & 14.193 & -0.253 & 181.187 & 606 \\
\hline
\end{tabular}

S.D: Standard Deviation. 
Appendix 2: Correlation analysis (uniform sample size: 319)

\begin{tabular}{|c|c|c|c|c|c|c|c|c|c|c|c|c|c|c|c|c|c|c|}
\hline \multicolumn{10}{|c|}{ Governance variables } & \multicolumn{4}{|c|}{ Knowledge Diffusion variables } & & \multirow{3}{*}{$\begin{array}{l}\text { Mobile } \\
\text { Phone }\end{array}$} & \\
\hline \multicolumn{3}{|c|}{ Political governance } & \multicolumn{3}{|c|}{ Economic governance } & \multicolumn{3}{|c|}{ Institutional governance } & \multirow[b]{2}{*}{ G.gov } & & \multicolumn{3}{|c|}{ Control variabies } & & \\
\hline PS & VA & Polgov & $\mathrm{GE}$ & $\mathrm{RQ}$ & Ecogov & $\mathrm{CC}$ & $\mathrm{RL}$ & Instgov & & Edu & STJA & Internet & GDPg & Popg & FDI & Aid & & \\
\hline \multirow[t]{16}{*}{1.000} & 0.678 & 0.909 & 0.649 & 0.574 & 0.634 & 0.661 & 0.802 & 0.765 & 0.811 & -0.366 & 0.014 & 0.377 & -0.070 & -0.314 & 0.009 & -0.114 & 0.338 & PS \\
\hline & 1.000 & 0.922 & 0.793 & 0.758 & 0.803 & 0.655 & 0.822 & 0.771 & 0.882 & -0.350 & 0.266 & 0.417 & 0.056 & -0.314 & -0.046 & -0.078 & 0.366 & VA \\
\hline & & & 1.000 & 0.868 & 0.969 & 0.808 & 0.888 & 0.887 & 0.940 & -0.292 & 0.351 & 0.449 & 0.025 & -0.410 & -0.054 & -0.205 & 0.441 & $\mathrm{GE}$ \\
\hline & & & & 1.000 & 0.963 & 0.682 & 0.790 & 0.770 & 0.874 & -0.294 & 0.353 & 0.288 & -0.007 & -0.349 & -0.078 & -0.235 & 0.394 & RQ \\
\hline & & & & & 1.000 & 0.774 & 0.870 & 0.860 & 0.940 & -0.357 & 0.364 & 0.384 & 0.010 & -0.394 & -0.068 & -0.227 & 0.433 & Ecogov \\
\hline & & & & & & 1.000 & 0.825 & 0.956 & 0.869 & -0.421 & 0.224 & 0.421 & -0.082 & -0.359 & -0.062 & -0.118 & 0.399 & $\mathrm{CC}$ \\
\hline & & & & & & & 1.000 & 0.954 & 0.961 & -0.406 & 0.163 & 0.462 & -0.030 & -0.371 & -0.039 & -0.145 & 0.403 & RL \\
\hline & & & & & & & & & 1.000 & -0.418 & 0.259 & 0.454 & -0.018 & -0.398 & -0.051 & -0.167 & 0.439 & G.gov \\
\hline & & & & & & & & & & 1.000 & -0.137 & -0.497 & 0.139 & 0.403 & -0.049 & 0.196 & -0.449 & Edu \\
\hline & & & & & & & & & & & 1.000 & 0.137 & -0.011 & -0.186 & -0.102 & -0.166 & 0.346 & STJA \\
\hline & & & & & & & & & & & & 1.000 & -0.042 & -0.455 & 0.060 & -0.183 & 0.697 & Internet \\
\hline & & & & & & & & & & & & & 1.000 & 0.181 & 0.197 & 0.124 & -0.099 & GDPg \\
\hline & & & & & & & & & & & & & & 1.000 & 0.065 & 0.419 & -0.404 & Popg \\
\hline & & & & & & & & & & & & & & & 1.000 & 0.209 & 0.099 & FDI \\
\hline & & & & & & & & & & & & & & & & 1.000 & -0.248 & Aid \\
\hline & & & & & & & & & & & & & & & & & 1.000 & Mobile \\
\hline
\end{tabular}

PS: Political Stability/Non violence. VA: Voice \& Accountability. Polgov: Political Governance. GE: Government Effectiveness. RQ: Regulation Quality. Ecogov: Economic Governance.

CC: Corruption-Control.RL: Rule of Law. Instgov: Institutional Governance. G.Gov: General Governance. Edu : Educational quality. STJA: Scientific \& Technical Journal Articles.

Internet: Internet Penetration. GDPg: GDP growth. Popg: Population growth. FDI: Foreign Direct Investment inflows. Aid: Foreign aid. Mobile: Mobile Phone penetration. 


\begin{tabular}{|c|c|c|c|c|c|c|c|c|c|c|}
\hline & \multicolumn{3}{|c|}{ Political Governance } & \multicolumn{3}{|c|}{ Economic Governance } & \multicolumn{3}{|c|}{ Institutional Governance } & \multirow[b]{2}{*}{ G.gov } \\
\hline & PS & VA & Polgov & GE & RQ & Ecogov & $\mathrm{CC}$ & RL & Instgov & \\
\hline $\mathrm{PS}(-1)$ & 0.965 & & & & & & & & & \\
\hline $\mathrm{VA}(-1)$ & & 0.982 & & & & & & & & \\
\hline Polgov(-1) & & & 0.981 & & & & & & & \\
\hline GE(-1) & & & & 0.979 & & & & & & \\
\hline $\mathrm{RQ}(-1)$ & & & & & 0.981 & & & & & \\
\hline $\operatorname{Ecogov}(-1)$ & & & & & & 0.986 & & & & \\
\hline $\mathrm{CC}(-1)$ & & & & & & & 0.967 & & & \\
\hline $\operatorname{RL}(-1)$ & & & & & & & & 0.985 & & \\
\hline $\operatorname{Instgov}(-1)$ & & & & & & & & & 0.984 & \\
\hline G.gov(-1) & & & & & & & & & & 0.990 \\
\hline
\end{tabular}

PS: Political Stability/Non violence. VA: Voice \& Accountability. Polgov: Political Governance. GE: Government Effectiveness. RQ: Regulation Quality. Ecogov: Economic Governance. CC: Corruption-Control. RL: Rule of Law. Instgov: Institutional Governance. G.Gov: General Governance.

\section{References}

Andrés, R. A, \& Asongu, S. A., (2013). "Fighting Software Piracy: Which Governance Tools Matter in Africa?", Journal of Business Ethics 118(3), pp. 667-682.

Andrés, R. A, Asongu, S. A., Amavilah, V. H., (2014). "The Impact of Formal Institutions on Knowledge Economy", Journal of the Knowledge Economy:

http://link.springer.com/article/10.1007\%2Fs13132-013-0174-3 (Accessed : 31/19/2015).

Anyanwu, J. C., (2012). "Developing Knowledge for the Economic Advancement of Africa", International Journal of Academic Research in Economics and Management Sciences, 1(2), pp. 73-111.

Anyanwu, J., \& Erhijakpor, A., (2014). "Does Oil Wealth Affect Democracy in Africa?"African Development Review, 26 (1), pp. 15-37.

Arellano, M., \& Bond, S., (1991), "Some tests of specification for panel data: Monte Carlo evidence and an application to employment equations" The Review of Economic Studies, 58, pp. 277-297.

Arellano, M., \& Bover, O., (1995), "Another look at the instrumental variable estimation of errorcomponents models", Journal of Econometrics, 68, pp. 29-52.

Asiedu, E., (2014). "Does Foreign Aid in Education Promote Economic Growth? Evidence From Sub-Saharan Africa", Journal of African Development, 16(1), pp. 37-59.

Asongu, S. A., (2013). "How has mobile phone penetration stimulated financial development in Africa", Journal of African Business, 14(1), pp. 7-18.

Asongu, S. A., (2014). "African development: beyond income convergence", South African Journal of Economics, 83(3), pp. 334-353.

Asongu, S. A., (2015a). "Conditional Determinants of Mobile Phones Penetration and Mobile Banking in Sub-Saharan Africa", Journal of the Knowledge Economy. 
http://link.springer.com/article/10.1007\%2Fs13132-015-0322-z

Asongu, S. A., (2015b). "Knowledge Economy Gaps, Policy Syndromes and Catch-Up Strategies: Fresh South Korean Lessons to Africa", Journal of the Knowledge Economy, http://link.springer.com/article/10.1007/s13132-015-0321-0

Asongu, S. A., (2015c). "The impact of mobile phone penetration on African inequality", International Journal of Social Economics, 42(8), pp. 706-716.

Asongu, S. A., (2015d). "Determinants of Growth in Fast Developing Countries: Evidence from Bundling and Unbundling Institutions", Politics \& Policy: Forthcoming.

Asongu, S. A., \& De Moor, L., (2015a). "Recent advances in finance for inclusive development: a survey", African Governance and Development Institute Working Paper No. 15/005, Yaoundé.

Asongu, S. A., \& De Moor, L., (2015b). "Financial globalisation dynamic thresholds for financial development: evidence from Africa", The European Journal of Development Research: Revised and Resubmitted.

Asongu, S. A., \& Kodila-Tedika, O., (2016). "Fighting African Conflicts and Crimes: Which Governance Tools Matter?” International Journal of Social Economics: Forthcoming.

Asongu, S. A., \& Nwachukwu, J., (2015a). "Revolution empirics: predicting the Arab Spring" Empirical Economics: http://link.springer.com/article/10.1007/s00181-015-1013-0

Asongu, S. A., \& Nwachukwu, J., (2015b). "Foreign aid and governance in Africa", International Review of Applied Economics: doi/abs/10.1080/02692171.2015.1074164

Ba, J., \& Ng S (2006). "Confidence intervals for diffusion index forecasts and inference for factor-augmented regression”, Econometrica, 74(4), pp. 1133-1150.

Bai, J., (2003). "Inferential theory for factor models of large dimensions". Econometrica, 71 (1),pp.135-173.

Bai, J., (2009). "Panel data models with interactive fixed effects". Econometrica, 77(4), pp. 1229-1279.

Baltagi, B. H., (2008). "Forecasting with panel data", Journal of Forecasting, 27(2), pp. 153173.

Barro, R., (1991). "Economic Growth in a Cross Section of Countries". Quarterly Journal of Economics 196 (2/May): 407-443.

Barro, R. J., \& Sala-i-Martin, X., (1992). “Convergence”, Journal of Political Economy, 100, pp. 223-251.

Barro, R. J., \& Sala-i-Martin, X., (1995). Economic Growth. The MIT Press, Cambridge, MA. 
Baumol, W. J., (1986). "Productivity, growth, convergence and welfare: what the long run data show", American Economic Review, 76, pp. 1072-1085.

Blundell, R., \& Bond, S., (1998). "Initial conditions and moment restrictions in dynamic panel data models" Journal of Econometrics, 87(1), pp. 115-143.

Bond, S., Hoeffler, A., \& Tample, J. (2001) “GMM Estimation of Empirical Growth Models", University of Oxford.

Brambor, T., Clark, W. M., and Golder, M., (2006). "Understanding Interaction Models:Improving Empirical Analyses”, Political Analysis, 14 (1), pp. 63-82.

Claus, I., \& Grimes, A., (2003). "Asymmetric Information, Financial Intermediation and the Monetary Transmission Mechanism: A Critical Review", NZ Treasury Working Paper No. 13/019, Wellington.

Dixit, A., (2009). "Governance Institutions and Economic Activity", American Economic Review, 99(1), pp. 5-24.

Efobi, U., (2015). "Politicians' Attributes and Institutional Quality in Africa: A Focus on Corruption", Journal of Economic Issues, 49(3), pp. 787-813.

Fonchingong, C., (2014). "Firming Up Institutional Policy for Deprived Elderly in Cameroon", Politics \& Policy, 42(6), pp. 948-980.

Fosu, A., (2013a), "Growth of African Economies: Productivity, Policy Syndromes and the Importance of Institutions" Journal of African Economies, 22(4): 523-551.

Fosu, A., (2013b). "Growth of African Economies: Productivity, Policy Syndromes and the Importance of Institutions" Journal of African Economies 22(4): 523-551.

Fosu, A. K., (2015a). "Growth, Inequality and Poverty in Sub-Saharan Africa: Recent Progress in a Global Context”, Oxford Development Studies, 43(1), pp. 44-59.

Fosu, A., (2015b). Growth and Institutions in African Development, First edited by Augustin K. Fosu, , Routledge Studies in Development Economics: New York

Fosu, A., (2015c). Growth and institutions in African Development, in Growth and Institutions in African Development, First edited by Augustin K. Fosu, 2015, Chapter 1, pp. 1-17, Routledge Studies in Development Economics: New York.

Fukuyama, F., (2013). “What is Governance?”, Governance, 26(3), pp. 347-368.

Fung, M. K., (2009). "Financial development and economic growth: convergence or divergence?". Journal of International Money and Finance, 28, pp.56-67.

Gagliardone, I., (2015). “'Can you hear me?' Mobile-radio interactions and governance in Africa", new media and society, doi: 10.1177/1461444815581148. 
Gani, A., (2011). "Governance and Growth in Developing Countries", Journal of Economic Issues, 45(1), pp. 19-40.

Greenaway-McGrevy, R., Han, C., \& Sul, D., (2012). "Asymptotic distribution of factor augmented estimators for panel regression”. Journal of Econometrics, 169 (1), pp. 48-53.

Hellstrom, J. (2008), "Mobile phones for good governance- challenges and way forward", Stockholm University / UPGRAID, http://www.w3.org/2008/10/MW4D_WS/papers/hellstrom_gov.pdf (Accessed: 22/11/2015).

Jolliffe, I. T. (2002) Principal Component Analysis (2nd Ed.) New York: Springer.

Kaiser, H. F. (1974) “An index of factorial simplicity” Psychometrika 39, pp. 31-36.

Kaufmann, D., Kraay, A., \& Mastruzzi, M., (2007a). "Growth and Governance: A Reply", Journal of Politics, 69(2), pp. 555-562.

Kaufmann, D., Kraay, A., \& Mastruzzi, M., (2007b). "Growth and Governance: A Rejoinder", Journal of Politics, 69(2), pp. 570-572.

Kaufmann, D., Kraay, A \& Mastruzzi, M., (2010). "The worldwide governance indicators: Methodology and analytical Issues”. World Bank Policy Research Working Paper No 5430, Washington.

Kuada, J., (2015). Private Enterprise-Led Economic Development in Sub-Saharan Africa The Human Side of Growth First edition by Kuada, J, Palgrave Macmillan: New York.

Kurtz, M., \& Schrank, A., (2007a). "Growth and Governance: Models, Measures, and Mechanisms”, Journal of Politics, 69(2), pp. 538-554.

Kurtz, M., \& Schrank, A., (2007b). "Growth and Governance: A Defense", Journal of Politics, 69(2), pp. 563-569.

Lalountas, D. A., Manolas, G.A., \& Vavouras, I.S., (2011), “ Corruption, globalization and development: How are these three phenomena related?", Journal of Policy Modeling, 33, pp.636-648.

Love, I., \& Zicchino, L., (2006). "Financial Development and Dynamic Investment Behaviour: Evidence from Panel VAR" .The Quarterly Review of Economics and Finance, 46(2), pp. 190-210.

Mankiw, N. G., Romer, D., \& Weil, D. N., (1992). "A contribution to the empirics of economic growth”, Quarterly Journal of Economics, 107, pp. 407-437.

Matthias, M., (2012). "Connectivity and Accountability in Africa", The Futurist, 46(1), pp. 67. 
Mayer-Foulkes, D., (2010). "Divergences and Convergences in Human Development". UNDP Human Development Research Paper 2010/20.

McKenzie C, R., \& McAleer M (1997). "On efficient estimation and correct inference in models with generated regressors: A general approach." Japanese Economic Review, 48(4), pp. 368-389.

Mpogole, H., Usanga, H., \& Tedre, M., (2008). "Mobile phones and poverty alleviation: a survey study in rural Tanzania", Proceedings of M4D 2008, Karlstad University, Sweden, pp. $62-72$.

Okada, K., \& Samreth, S.,(2012), "The effect of foreign aid on corruption: A quantile regression approach", Economic Letters, 11, pp. 240-243.

Oluwatobi, S., Efobi, U.R., Olurinola, O.I., Alege, P. (2015), "Innovation in Africa: Why Institutions Matter”, South African Journal of Economics, 83(3), pp. 390-410.

Oxley L, \& McAleer, M., (1993). "Econometric issues in macroeconomic models with generated regressors." Journal of Economic Surveys, 7(1), pp. 1-40.

Pagan, A., (1984). "Econometric issues in the analysis of regressions with generated regressors" International Economic Review, 25(1), pp. 221-247.

Penard, T., Poussing, N., Yebe, G. Z., \& Ella, P. N., (2012). "Comparing the Determinants of Internet and Cell Phone Use in Africa: Evidence from Gabon ", Communications \& Strategies, 86, pp. 65-83.

Pesaran, M. H., (2006). "Estimation and inference in large heterogeneous panels with a multifactor error structure". Econometrica 74 (4), pp. 967-1012.

Petrakis, P. E., \& Stamatakis, D. (2002). "Growth and educational levels: a comparative analysis”. Economics of Education Review, 21 (2), pp. 513-521.

Porter, G., Hampshire, K., Milner, J., Munthali, A., Robson, E., De Lannoy, A., Bango, A., Gunguluza, N., Mashiri, M., Tanle, A., and Abane, A., (2015). "Mobile Phones and Education in Sub-Saharan Africa: From Youth Practice to Public Policy", Journal of International Development, DOI: 10.1002/jid.3116.

Roodman, D., (2009a). "A Note on the Theme of Too Many Instruments", Oxford Bulletin of Economics and Statistics, 71(1), pp. 135-158.

Roodman, D., (2009b). "How to do xtabond2: An introduction to difference and system GMM in Stata", Stata Journal, 9(1), pp. 86-136.

Snow, B. C., (2009). "Mobile Phone Diffusion and Corruption in Africa", Political Communication, 26(3), pp.333-353.

Solow, R. M., (1956). "A contribution to the theory of economic growth", Quarterly Journal of Economics, 70, pp. 65-94. 
Stock, J. H. \& M. W. Watson (2002). "Forecasting using principal components from a large number of predictors". Journal of the American Statistical Association, 97 (460), pp.11671179.

Swan, T., (1956). "Economic growth and capital accumulation". Economic Record, 32, pp. 334-361.

http://onlinelibrary.wiley.com/doi/10.1111/saje.12100/abstract

Tchamyou, V. S., (2015). "The role of knowledge economy in African business", Journal of the Knowledge Economy: Forthcoming.

Tusalem, R. F., (2015), "State Regulation of Religion and the Quality of Governance", Politics \& Policy, 43(1), pp. 94-141.

Westerlund, J., \& Urbain, J-P., (2013a). "On the estimation and inference in factor-augmented panel regressions with correlated loadings", Economic Letters, 119, pp. 247-250.

Westerlund, J., \& Urbain, J-P., (2013b). "On the implementation and use of factor-augmented regressions in panel data", Journal of Asian Economics, 28, pp. 3-11.

Westerlund, J., \& Urbain, J-P., (2012). “Cross-sectional averages versus principal components", Maastricht University, RM/11/053.

World Bank (2015). "World Development Indicators", World Bank Publications http://www.gopa.de/fr/news/world-bank-release-world-development-indicators-2015 (Accessed: 25/04/2015).

Yerrabati, S., \& Hawkes, D., (2015). "Economic Governance and Economic Growth in South and East Asia \& Pacific Region: Evidence from Systematic Literature Reviews and Metaanalysis". Advances in Economics and Business, 3 , pp. 1 - 21. 